\title{
EESTI KULTUURILOOLISE ARHIIVI LAEKUMISI 2010-2012
}

\section{0}

Eesti Kultuuriloolise Arhiivi (EKLA) kogud täienesid kultuuriajalooliste materjalidega traditsiooniliselt vabatahtlike annetustena. Suuremad laekumised käsikirjade kogusse olid Ralf Parve, Anton Vaarandi ja Ants Järve käsikirjalised arhiivid, juba varem üle antud personaalarhiividele tõid lisa August Eelmäe ja Erast Parmasto.

Hoiustati taas õpilaste iga-aastased ajalooalased võistlustööd, Ivar Vilde andis üle oma matkapäevikud aastatest 1953-2005, arvele võeti poolsada elulugu ning eluloovõistluse „Minu elu ja seltsitegevus" 31 laekunud tööd. Ei saa alahinnata ka kultuuriajalooliselt olulisi üksiklaekumisi.

Väliseesti materjalidest olid mahukamad erinevate Uppsala Eesti organisatsioonide ja Ilmar Loorandi arhiivid, mõlemad sisaldasid ka fotosid. Ottawa Eesti saatkonna vahendusel ja BaltHerNeti kaasabil jõudis kultuuriloolisesse arhiivi kõvaketas Ottawas Kanada Arhiivis ja Raamatukogus (LAC) digiteeritud omaaegse kirjastuse Orto kirjavahetusega, mis on üks olulisemaid pagulaskultuuri ajalugu kajastavaid materjale.

Fotokogu säilikute arvu suurendasid oluliselt muuseumipoolsed pildistused mitmetest kultuuri- ja kirjandusüritustest. Olulist lisa tuli taas jätkuprojektist „Kirjanik ja tema keskkond”, mille raames pildistati kokku 25 kirjanikku nii Tallinnas, Tartus, Rakveres kui ka Võru-, Harju- ja Virumaal. Laekunud pildilisest materjalist võib nimetada veel fotosid seoses Anton Vaarandi, Egon Ranneti ja Ivar Ivaskiga, samuti omaaegsetest Pärnu-Jaagupi kultuuritegelastest.

Rootsist saadeti lisa juba korrastatud Teataja arhiivile. Kunstikogu mahtu suurendas oluliselt Tartu Eksliibrise- klubist Heikki Lahi poolt üle antud eksliibriste kogu, kokku 2604 säilikut. Kais Adlas annetas maalikogusse Miljard Kilgi portree Kaarel Irdist, Siimon Haamer Tartu Teoloogia Akadeemiast 60 kassetti Evald Saagi loengute salvestustega, mis täiendasid oluliselt helikogu. Arvuliselt olid laekumised järgmised: käsikirjade kogusse 3041 säilikut, fotokogusse 10497 säilitusühikut (neist digifotosid 3249), kunstikogusse 2622 sü, audiovisuaalsesse kogusse 130 säilitusühikut, lisaks 12 esemelist säilikut. Seega oli 2010. aasta laekumine kokku 16302 säilitusühikut.

\section{1}

Jätkus tavapärane kogumistöö. Ühelt poolt põhines see vabatahtlikel kultuuriajalooliste materjalide annetustel, teisalt oli see arhiivipoolne süsteemne ajalooainese koondamine ning kultuurisündmuste ja -isikute jäädvustamine.

Kõige mahukamad hoiustatud käsikirjalised personaalarhiivid olid Andres Vanapa, Leo Metsari, Helju Valsi, Fanny de Siversi ja Ilse Lehiste kogud, neist viimased saadeti EKLA-sse vastavalt Prantsusmaalt ja USA-st. Arvestatavad olid lisalaekumised Bernard Kangro, Valmar Adamsi, Elmar Kaldi ja Sõnavara kirjastuse ning õpilaste ajalooalaste võistlustööde materjalidele. Registreeriti MÜA (Metsaülikool Austraalias), Eesti Naisklubi Stockholmis, Uppsala Eesti skautide ja gaidide materjalide, Kirjanike Liidu, kultuuriministeeriumi võistlustööde, Endla Hermanni, Priidu Puusepa, Aldo Kalsi, Olaf Tammarki jmt arhiiviainese vastuvõtt, samuti aastakümneid hõlmavad Artur Adsoni ja Marie Underi kirjad Õie Fleigile Šveitsi, Vaino Vahingu kirjad Ilvi Jõe-Cannonile USA-sse ning mitmeid kultuuriajalooliselt olulisi üksiklaekumisi. 
Rutt Hinrikus suunas ja koordineeris elulugude kogumist. Oldi osalised Eesti Päevalehe ja ajakirja Akadeemia „Eesti mälu" sarja initsiatiivil toimunud eluloovõistluse toimumises, mille tulemusena laekus EKLA kogusse 45 elulugu. Lisaks arhiveeriti 16 säilikut mälestusi. Kokku registreeriti 5609 säilikut käsikirjalist originaalmaterjali.

Fotokogu sai lisa Salme Ekbaumi ja Endla Hermanni personaalarhiivide, Kalju Suure autorikogu, Eesti Naisklubi albumite ning teiste arvukate kultuuriajalooliste isikute ja sündmuste pildijäädvustustega. Oluliselt suurendasid fotokogu laekumiste arvu pildistused kirjandus- ja kultuurisündmustest. Projekti „Kirjanik ja tema keskkond" raames jätkus kirjanike, luuletajate, tõlkijate ja kirjandusteadlaste fotografeerimine nende endi poolt valitud keskkonnas. Seekord pildistati Harju-, Rapla-, Lääne- ja Hiiumaal ning Tallinnas ja Tartus kokku 25 literaati, mille tulemusena lisandus arhiivi 764 pildifaili. Valikuliselt, kuid valdavas enamuses on valmistatud vastavalt võimalustele digitaalsetest pildistustest ka tagatiskoopiad. Kokku laekus fotokogusse 6656 säilikut pildimaterjali.

Kunstikogusse lisandus ligi 800 eksliibrist Tartu Eksliibriseklubilt ja mitmeid graafilisi töid (844 säilikut). Audiovisuaalsesse kogusse laekus arvukalt kassette lindistustega kirjandus- ja kultuurilooliste isikute intervjuudest, mälestustest, esinemistest ning Eesti Muinsuskaitse Seltsi koosolekutest, vestlusringidest jm (161 säilikut), lisaks kultuuriloolisi filme (14 säilikut).

Kokku laekus EKLA käsikirjade, foto-, kunsti-, heli- ja filmikogusse 13284 säilitusühikut.

\section{2}

Kogumistöö toimus endiselt vabatahtlike annetuste kaudu, teisalt aga ka arhiivipoolse sihipärase tegevusega, en- nekõike fotoarhiivi täiendamisel (jätkuprojekt „Kirjanik ja tema keskkond” ning jooksvate kultuurisündmuste jäädvustamine) ja elulugude kogumisel (üleskutse õpetajate elulugude kogumiseks). Käsikirjakogusse tuli märkimisväärset lisa eelnenud aastatel laekunud Ilse Lehiste, Helga ja Enn Nõu, Tiiu Viires-Haameri, Aldo Kalsi, Aarne Vinkeli, Vaino Vahingu ning Heino Rossi isikuarhiividele.

Suur kogus arhiivimaterjali anti üle kirjastusest Eesti Raamat, sh 1996. aasta romaanivõistluse tööd. EKLA-sse jõudis Ilmar Laabaniga seotud materjale, avaldatud ja avaldamata käsikirju, tõlkeid jm. Eesti Ajalooõpetajate Selts hoiustas järjekordsed opilaste ajalooalased uurimistööd. Personaalsete kirjandus- ja kultuurilooliste materjalide järkjärgulist üleandmist alustasid teatriteadlane Lea Tormis, kunstnik Jüri Arrak ning ajakirjanik ja kirjanik Enda Naaber. Oma perekonna päevikuid saatis arhiivi USA-s elav Taavo Virkhaus ning väärtuslikku kirjavahetust Austraalias elav tuntud eestluse hoidja Arvi Vainomäe. Teiste isikute vahendusel jõudsid EKLA-sse Argentiina Eesti Seltsi materjalid, isikuarhiividest ajakirjaniku Uno Lehepuu, näitekirjaniku ja tõlkija Liidia Kompuse ning väliseestlase Irene Tedersoo peamiselt kirjavahetusi sisaldav arhiiviaines. Esile tuleb kindlasti tõsta ka üle antud pikemaajalisi kirjavahetusi (Elmar Pettai, Hillar Palamets, Jüri Arrak, Rein Põder).

Ühenduse Eesti Elulood üleskutse koguda õpetajate mälestusi tõi kogusse juurde 30 elulugu.

Fotokogu täienes ühtekokku 10270 säiliku võrra, milledest enam kui pooled on sihipärased jäädvustused. Jätkuprojekti „Kirjanik ja tema keskkond” raames pildistati 43 kirjanikku Tartus, Tallinnas, Harju-, Lääne-, Pärnu-, Valga- ja Viljandimaal (kokku 1240 fotot). Regulaarselt jäädvustati aasta jooksul toimunud konverentse, seminare, raa- 
matuesitlusi jt kirjandus- ja kultuurisündmusi. Arhiveeritud digitaalsetest pildistustest valmistati valikuliselt ka tagatiskoopiad. Suures koguses kultuuriajaloolisi fotosid annetas kodu-uurija Heino Ross: üle 800 foto ja negatiivi ning ligi 200 fotot laekus Tiiu ViiresHaameri arhiiviga, mis on peamiselt seotud Göteborgi Eesti Seltsi näiteringi tegevusega.

Kunstikogu sai lisa Richard Kaljo raamatuillustratsioonidest (477 säilikut), vastu võeti Aleksander Kaasiku Lydia Koidula büst, Eduard Ole pliiatsijoonis Karl Ristikivist, Nikolai Bulgarini joonistus Ilmar Isopist, kaks Karl Taevi maali ja Mati Metsaviiru eksliibriseid.
Audiovisuaalne kogu täienes mitmete intervjuudega: Harri Kiisa vestlused ja intervjuud Eduard Tubina ja Juhan Aavikuga ning vestlussaated Vaba Eesti Raadios Stockholmis; Tiina Kirsi intervjuud Jaan Krossiga; Hasso Krulli intervjuu Ilmar Laabaniga; Ivar Ivaski loengud ja esinemised Eestis.

Kokku laekus 12768 säilitusühikut käsikirju, fotosid ja negatiive (sh digitaalseid pildistusi), kunstitöid ning helisalvestusi.

VILVE ASMER

Andmed on esitatud aruandena Haridus-ja Teadusministeeriumile. 